\title{
Veidenbauma nezūdamības likums
}

\author{
Marians Rižijs
}

\begin{abstract}
Kopsavilkums
Rakstā aplūkots dzejnieka Eduarda Veidenbauma popularitātes fenomens latviešu dzejā, šã fenomena iemesli, specifika un izmaiņas laika gaitā. Var nosacīti nošķirt literāros un ārpusliterāros faktorus. Pie ārpusliterārajiem faktoriem minama Veidenbauma īsās dzīves un nāves leǵenda, kas atbilst romantisma iedibinātajam agri mirušo dzejnieku kultam. Šĩs leǵendas veidošanā, tāpat kā literārā un zinātniskā mantojuma saglabāšanā un popularizēšanā, liela nozīme bija vina draugiem. Šì leǵenda ir atvērta, taču kompakta struktūra, kurā zināmo un nezināmo elementu samērs l̦auj nepieciešamos elementus izcelt un sakārtot atbilstoši katra nākamā laikmeta oficiālās ideolog̣ijas vajadzībām. Taču zem ideoloǵiskās virsbūves parasti varējusi saglabājusies arī tā Veidenbauma leǵgendas un daiḷrades daḷa, kas disonē ar oficiālo laikmeta traktējumu. Savukārt pie literārajiem faktoriem minams, ka Veidenbauma dzejas atklāšana 19. gadsimta 90. gadu pirmajā pusē iezīmē lūzuma punktu latviešu dzejas literāro paradigmu maiņā. Neviens cits dzejnieks nav spējis panākt tik lielu vispārinājuma pakāpi, izmantojot abstraktus jēdzienus, kombinācijā ar emocionālu tiešumu un izteiksmes konkrētību.
\end{abstract}

Raksturvārdi: 19. gadsimts, dzeja, laikmets, ideoloǵija, paradigmu maiņa.

Eduarda Veidenbauma fenomenu latviešu dzejā savulaik visprecīzāk, šķiet, ir formulējis literatūrzinātnieks un Veidenbauma Rakstu sakārtotājs Rūdolfs Egle:

[..] latviešu literatūrā Veidenbauma dzejām negaidīti ienākušas un strauji aptrūkušas ieskaņas raksturs. Veidenbaums nepaceḷas mūsu Olimpā pa parasto attīstības teku, un nav vinam sekotāju. [..] individuālais nemiers, pārbaudītāja šaubas un sāpju traǵika atgādina to psiholog̣iju, kādu plašākā, raibākā rakstā tālāk auduši Poruks, Rainis, Aspazija, Plūdons. Neviens tomēr nav tā pacēlies atziṇu augstumos, paliekot reizē uz mūsu zemes, kā Veidenbaums. ${ }^{1}$

Veidenbauma aktualitātes fenomens latviešu dzejā ir daudzslān,ains, un to nosaka vairāki faktori, kurus ērtības labad varētu iedalìt literārajos un nosacīti

1 Egle, R. Eduards Veidenbaums dzīvē un darbos. Grām.: Eduarda Veidenbauma Raksti. R. Egles red. Cēsis; Rīga: O. Jēpes izdevniecība, 1926. 189. lpp. 
ārpusliterārajos. Turklāt šie faktori ir tik cieši savijušies viens ar otru, ka tos nav iespējams pilnībā noškirirt.

Starp nosacīti ārpusliterārajiem faktoriem, pirmkārt, minama Veidenbauma īsās dzīves un nāves leǵenda, kas gandrīz perfekti atbilst romantisma iedibinātajam agri mirušo dzejnieku kultam. Šajā leǵendā iederas gan Veidenbauma daudzpusīgā apdāvinātība un zināšanas krietni pāri vidusmēram dažādās humanitāro un eksakto zinātṇu nozarēs, gan ìsais mūžs, kurā realizēta tikai niecīga daḷa no radošā potenciāla (turklāt dzejai šeit atvēlēta neliela daḷa), nāve no smagas slimības, neordināra uzvedība, kas brīžiem pārkāpj sabiedrības iedibinātās normas. Un, visbeidzot, novēlotā pēcnāves slava. Līdzās dokumentālajām liecībām, kas glabājas Latvijas atmiņas institūcijās, pastāv Veidenbauma draugu, laikabiedru atmiṇas par dzejnieku, kā arī nostāsti, uz kuru pamata veikta viṇa personības rekonstrukcija, kas, lai cik godprātīga būtu, ir cilvēciski subjektīva un veido pamatu leǵendai. Lielā mērā šĩs atmiṇas ir tapušas, jau rēḳinoties ar Veidenbauma leǵendas aprisēm, un tādējādi apzināti vai neapzināti pakḷautas "iekšējai redakcijai".

Tomēr Veidenbaums ir pirmais dzejnieks latviešu dzejas vēsturē, kura īsās biogrāfijas leğenda neaizsedz viṇa dzejas nozīmi. Tā pirms Veidenbauma nav laimējies nedz Jurim Alunānam, nedz Miḳelim Krogzemim (Auseklim). Tieši Veidenbauma klātesme turpmākajā latviešu dzejas ainā ienes modernitātes elementu, kurš ik pa brīdim aktualizējas visos vēlākajos literatūras attīstības posmos. Dažā ziņā viṇa leǵenda kḷuva par modu, kurā latviešu literatūras vēsturē tiek veidota citu izcilu, agri mirušu dzejnieku dzives un nāves leǵenda (Jānis Ziemel̦nieks, Austra Skujiņa, Vilis Cedriņš, Uldis Leinerts, Klāvs Elsbergs, Ieva Roze u. c.). Un no šā moda vairs ìsti nav šķirama arī šo dzejnieku daiḷ̂rades uztvere.

Otrkārt, šìs leǵendas daḷa un turpinājums ir Veidenbauma rokrakstu liktenis - viņš mūsu kultūras apzin̄ā kā dzejnieks pastāv, tieši pateicoties Veidenbauma draugu savāktajiem un saglabātajiem viṇa dzejoḷu norakstiem, par kuru precizitāti vēl nav pilnīgas skaidrības (tas ir niecīgs apjoms - 74 dzejoḷi; paša dzejnieka rokrakstā saglabājušies tikai daži dzejoḷi un to uzmetumi). Zudušie Veidenbauma daiḷrades artefakti un hipotētiskā iespēja tos atrast savā ziṇā leǵendai pieškir papildu aktualitāti.

Šì leǵenda ir atvērta, taču pietiekami kompakta struktūra, kurā zināmo un nezināmo elementu samērs l̦auj nepieciešamos elementus izcelt un sakārtot atbilstoši katra nākamā laikmeta oficiālās ideologijas vajadzībām. Taču zem ideologíiskās virsbūves parasti varējusi saglabājusies arī tā Veidenbauma leǵendas un daiḷrades daḷa, kas disonē ar oficiālo laikmeta traktējumu, t. sk. galēji pesimistiskā un anakreontiskā lirika, kura īsti neiederējās nedz 20. gadsimta 30. gadu Ulmaṇa autoritārā pozitīvisma gaisotnē, nedz Padomju Latvijas socreālisma ierāmējumā. Savā ziṇā līdz ar ideologísko atkusni kopš 50. gadu otrās puses Veidenbauma motīvi vai veltījumi viņam² ${ }^{2}$ lauj latviešu dzejniekiem Ēzopa valodas dubultkodā

2 Čaklais, M. Eduardam Veidenbaumam; Skujenieks, K. Eduarda Veidenbauma dzīvojamā platība; Peters, J. “- Veidenbaums esot dzēris...”, 1891. gada decembris. Veidenbaums iet uz Kalāčiem; Ziedonis, I. Divdūjinas; Rokpelnis, J. Pēc Kalāčiem. Grām.: Veidenbaums, E. Dzeja. Rīga: Nordik, 2005. 93.-102. lpp. 
iedzīvināt režīmam opozicionāra protesta noskaṇas un dot mājienu uz Veidenbauma dzejas antiideoloǵisko patosu.

Tomēr šis nosacīti ārpusliterāro faktoru kopums ir sekundārs attiecībā uz tā laika latviešu dzejas attīstības ainu un negaidīti likumsakarīgo Veidenbauma vietu tajā. Viņš sava laika dzejā ienāk it kā ārpus konteksta, turklāt pats sevi šajā kontekstā neieraksta. Savā ziṇā viṇa dzejas "veiksmes stāsta" iemesls ir Veidenbauma apdāvinātības un vienaldzības pret savas dzejas publicitāti kombinācija. Vispusīgi izglìtots humanitārajās un eksaktajās zinātnēs un savas dzives laikā ārpus draugu loka pazīstams vienīgi kā Tērbatas Universitātes students, Veidenbaums pats sevi neuzskatīja par dzejnieku. Tātad viṇam dzīves laikā nenācās pildīt publisku dzejnieka lomu, kura uzliek par pienākumu būt arī noteiktas nacionālas, sociālas ideologijas paudējam, kā arī uzvesties atbilstoši sabiedrībā iedibinātam priekšstatam par dzejnieku. Latvijas dzejā kḷūdams leǵitīms jau kādu laiku pēc savas nāves, turklāt pastāvēdams puslegālā statusā arī pēc sava drauga Edvarda Treimaṇa-Zvārguḷa sastādītās pirmās dzejas izlases (1896), viṇš tā arī palika savrupa figūra latviešu dzejas ainavā bez tiešiem sekotājiem un pēctečiem, kaut arī viņa radītais ietekmēja daudzus nākamās paaudzes dzejniekus. Jāpiekrīt literatūrzinātnieka Raimonda Brieža teiktajam, ka par dzejnieku Veidenbaums ticis izveidots jau pēc vina nāves. ${ }^{3}$

Brīvība no šādas publiskas dzejnieka lomas pildīšanas Veidenbaumam l̦āva būt brīvam arī dzejā - stilistikā, formveidē, tēmu izvēlē, leksikā un emocionālajā nospriegojumā -, nerēḳinoties ar sava laika dzejas tradīcijas uzliktajiem rāmjiem.

19. gadsimta 80. gadi, kuros Veidenbaums rada lielāko daḷu dzejoḷu, bija tautiskā romantisma pagrimuma laiks, kurā iezīmējas reālisma paradigmas dominante. Dzejā valda sentimentālais romantisms, pret kuru Veidenbauma attieksme bija ironiska, pat sarkastiska. Taču tēmu izvēlē un poētikā ir iezīmes, kas l,auj sentimentālo romantismu kā individuālā romantisma paveidu uzskatīt par agrīnā modernisma priekšvēstnesi latviešu literatūrā (padziḷināta pievēršanās indivīda jūtu pasaulei, melanholisku noskaņu intensificēšana, emancipācija no nacionālās piederības, tautiskā romantisma nacionālā koda devalvēšanās). Savā veidā tieši šìs īpatnības - pasaules redzējums caur individuālā "es" izjūtu šķautni, kā arī dzejas formas tuvināšana zing̣gei (pilsētas romancei) - ir dažas no 80. gadu dzejas iezīmēm, kas dažā ziṇā atbalsojas arī Veidenbauma dzejā. Precīzi šìs iezīmes savulaik raksturojis Rūdolfs Egle:

Savā vienkāršībā vārds Veidenbaumam patura savu emocionālo dabu, tamdēḷ dzeja viegli iespiežas atmiņā. Šinī ziņā anakreontiskos iespaidus papildinājušas vēl [19. gadsimta] 70. un 80. gados tautā izplatīto "ziṇguu” skan,as. Ziṇğe vislielākā mērā apvieno tos elementus, vieglu ritmiku, tēla kustību, jūtekliskumu, kas ieviḷno tieši. [..] Šìs dzejas nav

3 Liniņš, E. Veidenbaums - spilgta personība literatūras vēsturē, katram laikam citāds. Pieejams http://lr1.1sm.lv/lv/raksts/siis-dienas-aciim/veidenbaums-spilgta-personiba-literaturasvesture-katram-laikam-.a93259/ [sk. 05.10.2019.] 
iespējams lasīt, nepadodoties viṇu melodiskai uzbūvei, tāpēc tauta tai drīz vien pielāgoja vienmuḷi-vienkāršu meldiju. ${ }^{4}$

Tāpēc likumsakarīgi, ka Veidenbauma parādīšanās 90. gadu pirmajā pusē uz latviešu dzejas skatuves iezīmē lūzuma punktu literāro paradigmu maiñā.

Veidenbauma dzejas izteiksme ir tik skaidra un viegli uztverama arī "vienkāršam" dzejas lasītājam un nodrošina viṇa empātisko identificēšanos ar dzejas varoni. Tieši tāpēc, ka pastāv ikvienam lasītājam atpazīstami emocionālie kodi, kuriem var viegli pieslēgties: pozitīvā-negatīvā kontrasts, sociālā netaisnība un protests pret to, cilvēka bezspēcība likten,a priekšā, anakreontiskie motīvi, Veidenbauma dzeja uzrunā gan "vienkāršo lasītāju”, gan intelektuāli izglītotu dzejas baudìtāju.

Šo kodu iedarbību pastiprina arī dzejas formālā puse - dinamisks ritma zīmējums, skanīgas aliterācijas, vienzilbes atskaņas, dinamiska tēlu maiņa. Ikvienam jaunam cilvēkam ir viegli uztvert šos kodus, jo jaunības sakāpināto emocionālo stāvokḷu mainu, to ietekmēto kontrastaini melnbalto pasaules ainu Veidenbaums pratis iedzīvināt īpaši suǵestējoši. Taču zem šā vieglāk uztveramā slāṇa pastāv vēl dziḷāki, kuru dẹḷ intelektuāls dzejas baudītājs arī mūsdienās novērtēs Veidenbauma dzeju. Neviens cits dzejnieks nav spējis panākt tik lielu vispārinājuma pakāpi, izmantojot abstraktus jēdzienus kombinācijā ar emocionālu tiešumu un izteiksmes konkrētību. Turklāt šis vispārinājums izaudzē gluži personisku eksistences traǵiku līdz ontologiskiem pasaules fundamentālas netaisnības mērogiem, kas vēl jo izasinātāki kḷūst kontrastā ar objektivizēto, distancēto eksistences vērojumu. Antinomijas netiek atrisinātas līmenī, kurā tās dzimušas, visbiežāk dzejoḷa fināls paliek eksistenciālās bezizejas situācijā vai rezignētā situācijas konstatējumā. Savā ziṇā šis emocionālo stāvokḷu un eksistenciālo situāciju kopums atklājas tikai visas dzejoḷu kopas apjomā, nevis koncentrēts kādā atsevišḳā dzejolī. Var teikt, Veidenbauma dzeja ir atvērtā fināla dzeja, kas nepiedāvā gatavus, noapaļotus risinājumus. Veidenbauma uzdevums nav bijis nedz sev, nedz lasītājam sniegt formāli noapal,otas, noslīpētas dzejas paraugus. Tādēḷ visas Veidenbauma pēcnāves dzejas izlases un viņa darbu apkopojumi, citiem vārdiem, formāts, kurā Veidenbauma dzejas mantojums ir pie mums nonācis, drīzāk piedāvā lasītājam pašam salikt akcentus un savā apziṇā izveidot gan krājumu, gan arī pašu Veidenbaumu. Varbūt, ja Veidenbauma dzejas un leǵendas piemērošana noteiktam laikmeta pieprasījumam lielā mērā bija noteiktas ideologijas darbs, tad šodien ir pienācis laiks katram Veidenbaumu atklāt individuāli bez ideolog̣iju ierāmējuma.

${ }^{4}$ Egle, R. Eduards Veidenbaums dzīvē un darbos, 176. lpp. 


\section{Veidenbaums's principle of permanence}

\section{Marians Rižijs}

The article discusses the phenomenon of popularity of Eduards Veidenbaums in Latvian poetry - its causes, specifics and evolution over time. A distinction can be made between literary and non-literary factors. Among the non-literary factors, the legend of Veidenbaums's short life and premature death can be mentioned. It sits well with the cult of prematurely dead poets established by Romanticism. To a large extent, his friends played a major role in the creation of this legend, as well as in the preservation and promotion of his literary and scholarly heritage. This legend is an open but compact structure where the ratio of known and unknown elements allows various emphases and can be arranged according to the needs of the official ideology of each subsequent era. However, also that part of Veidenbaums's legend and creativity, which dissonates with the official interpretation of the time, would survive under the ideological siege. In turn, among the literary factors, attention should also be paid to the discovery of Veidenbaums's poetry in the first half of the 1990s in Latvian poetry scene, thus marking a turning point in the change of literary paradigms. No other poet has been able to achieve such a high degree of generalization using abstract concepts in combination with emotional directness and concreteness of expression.

Keywords: $19^{\text {th }}$ century, poetry, era, ideology, paradigm shift. 